\title{
Impact of innovation and international networking on firm openness to foreign markets strategy in Middle East and North Africa: individualism' moderating effect
}

\section{Abderrahim Barakat*, Najlaa El Cati and Meriem Filali}

\author{
Hassan II University, \\ Casablanca, Morocco \\ Email: abderrahim.barakat@gmail.com \\ Email:najlaa.cati@gmail.com \\ Email: uh2.meriemfilali@gmail.com \\ *Corresponding author
}

\begin{abstract}
Firms are constantly looking for ways to succeed, exporting seems to be one of the most efficient means to do it. So as we can say exporting has a double aim, from a microeconomic point of view, it allows the firm to find new opportunities and from a macroeconomic point of view, it increases the growth level. This article main question treats the effects of innovation, international networking and socio-cultural differences within countries on the entrepreneur's decision to adopt or neglect exporting strategy. To do this, we used a linear hierarchical model based on 8,605 firms from 15 different countries in the MENA region, the data comes from the Global Entrepreneurship Monitor (GEM) database. This study brought some interesting results, in which we conclude on the moderating effect of individualism on networking, in the main time we've demonstrated that innovation and individualistic culture are positively linked to exporting decision-making.
\end{abstract}

Keywords: export; innovation; international networking; individualism; MENA region.

Reference to this paper should be made as follows: Barakat, A., El Cati, N. and Filali, M. (2020) 'Impact of innovation and international networking on firm openness to foreign markets strategy in Middle East and North Africa: individualism' moderating effect', MENA J. Cross-Cultural Management, Vol. 1, No. 1, pp.101-122.

Biographical notes: Abderrahim Barakat is currently a $\mathrm{PhD}$ student in Entrepreneurship, member of the University Hassan II Entrepreneurship and Organizational Management Laboratory in Casablanca, Morocco, and member of the Global Entrepreneurship Monitor-Morocco. In 2009, he obtained his Master's degree in Marketing and Organizational Communication at the National School of Business and Management. He is interested in quantitative studies of several issues such as business survival, growth expectations, entrepreneurial intention and motivation, and is the author of several research papers on the above-mentioned issues. He has extensive experience in higher education in economics and management at several institutions since 2012. 
Najlaa El Cati is a PhD student at the Faculty of Legal, Economics and Social Sciences of Casablanca. Currently, she is a communication skills teacher and a research project supervisor. She has followed a path that promotes economics and entrepreneurship. She graduated with a Bachelor's degree in Economics and Management at ENSET-Mohammedia and a Master's degree in Entrepreneurship and Organizational Management at FSJES-Casablanca. Her academic background has led her to become a training and recruitment consultant. She is an active member of the GEM team, She is also author of several works regarding entrepreneurship.

Meriem Filali is a PhD student at the Faculty of Law, Economics and Social Sciences of Casablanca. She is currently teaching human resources management as well as personal and professional development to undergraduate students. Over the years, she has developed an interest in education and training. In 2008, she obtained her Master's degree in the Management of Human Resources at INSEEC Paris. In 2014, she joined the world of academia to obtain another Master in the Management of organizations, and began doctoral research on entrepreneurial resilience. She is also author of several works and publications.

\section{Introduction}

Firms are obliged to differentiate themselves to offer the best service and product to the customer. A customer who is becoming more demanding, looking for the best offer in terms of quality/price (Jiménez-Guerrero et al., 2018). To increase their market shares, firms need to export and conquer new markets, and to strengthen their approach, they must resort to innovation. Actually, innovation plays the role of an export motivator (Rodil et al., 2016).

Innovative firms are more likely to succeed in foreign markets. In fact, it allows them to present innovative products and services to foreign customers and attract them (Baker et al., 2016). Exporting is a powerful advantage that a firm can rely on for a better result (Bai et al., 2017). Being in contact with influential personalities, either through their knowledge or their networks, living in foreign countries can help entrepreneurs to break into target markets. Thus, we assume that the entrepreneur's international network facilitates and increases the chances of the company to penetrate foreign markets (Ashourizadeh et al., 2014).

Research has identified innovation as a competitive advantage, which companies can use to penetrate new markets (Gaussens and Movahedi, 2015). In our first hypothesis, we will examine whether innovation has a positive effect on the level of exports of firms. According to Prashantham (2006) the entrepreneur's international network is a major asset for the development of his company and to increase its performance. Moreover, the network can provide richness in opportunities and potential binding. Due to the importance of the entrepreneur's international network, we would like to examine if international networking affects exporting positively.

A society's culture plays an important role in shaping an entrepreneur's personality, attitudes and values (Hills, 2002). Individualistic societies advocate the separation of the individual and the collective, and subordinate the group to the personal distinctiveness of the individual. Collectivist societies advocate interdependence between individuals and 
subordinate the pursuit of individual goals to the harmony of interpersonal relations in the group. Regarding our study, we are interested in the individualistic dimension. This article tries to answer the following question: how innovation and entrepreneur's international network influence export's level? Our objective is to study the contribution of innovation and the international network of the entrepreneur in the adoption of export as a strategy and also to find out whether these predictors have the same influence from one country to another in the MENA region. The knowledge gap lies in the fact that no article addresses and combines these three dimensions: innovation, exporting and international networking in view of the influence of the environment. The contribution of this paper is firstly a theoretical contribution through a literature review and a second empirical one which takes the form of a verification of hypotheses and theories dealing with the subject in the light of the influence of the environment in the MENA region.

This article is presented as follows: the first part is devoted to the theoretical framework in which we develop more specifically, on the one hand, the roles of innovation and the social network in the internationalisation of firms, and on the other hand, the effect of the context approached by the society's individualism. The second part presents the methodology, the source of the data used and the variables. Then, the third part will present the results of the research and test hypotheses previously put forward. Then we conclude by opening perspectives by considering the influence of the context.

\section{Theories and hypotheses}

\subsection{The effects of innovation on exports}

Innovation is one of the most important drivers of competitiveness and a major creator of wealth. It plays an important role in organisational and economic development, as evidenced by the large scope and the literature (Gaussens and Movahedi, 2015). The ability of a business to generate export earnings is often seen as a positive indicator of success. Innovation activities seem to play an important role in explaining differences in performance and export activities of firms. These are the main implications of recent economic theories on international trade and also the results of most studies on the relation between export and innovation activities at the firm's level in different sectors (Wakelin, 1998).

Although the literature considers innovation and exports as two separate activities, they have a strong impact on one another (Schmitt et al., 2002). In fact, the studies show the strong link between innovation and export (Love and Roper, 2015).

Several authors (Sousa et al., 2008; St. Pierre et al., 2006, 2012) support the idea that innovation plays a major role in the success of export companies. In fact, St. Pierre et al. (2012) consider innovation as a key to the entry the international markets. According to their analysis, innovation has two effects on exports:

- a first very indirect point: innovation defines the 'strength' of the product, which is considered a key to success

- there is then a direct effect: innovation makes it possible to adapt the product to export. 
Innovation would often be seen as a strategy to counter competition in foreign markets (St. Pierre et al., 2010). St. Pierre et al. (2015) underline that innovation is essential for the company because it allows it to distinguish itself on foreign markets and remain competitive through original knowledge, the design of new products or new services. This innovation effort gives the company the opportunity to adapt as well as possible to the demands of customers, suppliers or distributors and to react quickly to its potential competitors (St. Pierre et al., 2012).

The causality paradigm is dedicated to analyse the link between innovation and export, it argued that the causality may run from innovation to export, as well as vice versa (Filipescu et al., 2013; Golovko and Valentini, 2011). Two theories support the causality paradigm, the self-selection theory and the learning-by-exporting theory. The self-selection theory supports the fact that innovation has a positive impact on export (Bravo-Ortega et al., 2014). Pla-Barber and Alegre (2007) have tested the theory of self-selection, through a survey of 120 French companies of all sizes, from the biotechnology sector. The results obtained seem to be in line with the theory of self-selection. They indicate that innovation gives the firm a competitive advantage, which allows it to achieve a higher overall performance and improve its resources (Boso et al., 2013). Moreover, it allows the firm to be more competitive in foreign markets and facilitates its internationalisation. Innovation can therefore be considered as a condition facilitating export (Raymond and St. Pierre, 2013). It is emphasised that the nature of the impact of innovation on internationalisation depends on the context of the firm (origin, size, sector of activity) (Altomonte et al., 2013). Authors who have been interested in the theory of self-selection believe that innovation has a positive impact on exports (Boso et al., 2013; Monreal-Pérez et al., 2012).

Many studies have demonstrated the causal relationship between innovation and the level of firms' exports, process and product innovations have a positive effect (Caldera, 2010; Filipescu et al., 2013; Lachenmaier and Wößmann, 2006; Pla-Barber and Alegre, 2007). Launching a new product or elaborate a new process separately does not encourage export, but implementing both of them simultaneously have a much stronger positive impact (Becker and Egger, 2013). For Caldera (2010) innovation pushes firms to export relatively, since that process innovation has a lower impact than product innovation. This result is explained by the fact that product innovation allows a strong differentiation from competitors in the foreign market as well as a higher product quality, which gives a greater competitive advantage than process innovation (Becker and Egger, 2013).

Through the study of Spanish firms, Máñez-Castillejo et al. (2009), highlighted three direct-indirect links concerning the relationship between productivity, innovation and export. Productivity has a direct impact on exports. As productivity increases, the firm moves more toward exports to find new customers for their surplus. Similarly, productivity improves the probability of implementing an innovation process that promotes exports. The innovation process increases the firm productivity, which improves their export probability (Cassiman et al., 2010).

Deng et al. (2014) believe that the link between innovation and export can be negative and that we must take in consideration the firms heterogeneity. The authors show that, despite the fact that for Chinese manufacturing firms, innovation has a positive impact on the intensity of export, this impact is not necessarily positive to survive on the foreign market. Overall, works and studies conducted on the theory of self-selection 
highlights major disparities due to the sector of activity, firms size or the type of innovation wanted (product or process).

The relation between innovation and export behaviour is complicated. Innovation is, indeed, a key factor in the successful market entry based on the Schumpeterian growth model (creative destruction). Indeed, product innovation would provide a competitive advantage that would enhance the firm's chances to enter a competitive foreign market.

According to international trade theories, innovation can introduce new products into the international market or diversify the commodities used for trade, which can provide a significant margin for export growth (Grossman and Helpman, 1989). Innovation can stimulate and increase the quantity of exports by increasing firm productivity (Eaton and Kortum, 2002) or by improving product quality (Grossman and Helpman, 1991). In fact, company's productivity could be improved through innovation, which can increase its export success (Aw et al., 2008; Bustos, 2011; Caldera, 2010).

H1 Innovation affects positively firms' export levels.

\subsection{Role of international networking}

Several authors of resource-based view theory have studied social network mainly referring to internationalisation and international entrepreneurship. Social capital is a set of entities that are different from each other, with the common feature of a social structure and the fact that they facilitate some of the agent's actions (Coleman, 1988). It is a network based on material and symbolic exchanges between agents and depends on the quality and size of an individual's relational structure and allows him to mobilise by proxy the capital of a group (family, former classmates, select club, ...) (Bourdieu, 1980). The quality of social capital allows some activities to access valuable information at an early stage, thus providing a competitive advantage. Burt (1995) argues that a network provides access to more information than one person can obtain.

The entrepreneur's network refers to all the individuals that an actor knows personally. According to sociologists, 'to know personally' refers to all personal relationships with the actor, designated by ego, who have established contact at least once: it can include family, friends, co-workers, suppliers, customers, public (administration ...) or private (bank ...) institutions, etc. In addition to that, Dubini and Aldrich (1991) define the personal network: "All persons with whom the entrepreneur has direct relationships (or, in some cases, indirect relationships through direct relationships). For entrepreneurs, we can think of partners, suppliers, customers, venture capital, banks or other funders, distributors, trade associations and family members." We note that these definitions focus on the role of the entrepreneur's network without talking about the relations with people living abroad or who have come from abroad. Therefore, we will analyse further the impact of relationships that the entrepreneur has with contacts abroad.

The studies conducted by Chetty and Holm (2000) show that networks contribute significantly to the success of the business by helping entrepreneurs identify new opportunities abroad and by improving their knowledge of markets, products and key players. In a study based on 52,946 firm, Ashourizadeh et al. (2014) showed that the effect of receiving advice from an international network has a greater impact on exports than other kinds of networks and more than entrepreneur's education. 
Johanson and Mattsson (1988) introduced network theory to the international context, based on social exchange theory and resource dependence theory. Network theory argues that the internationalisation of firms is a phenomenon related to networks. The authors observed that firms used diverse networks to ease their activities in foreign markets. The network model of internationalisation describes that firms develop relationships with customers and suppliers. In other words, internationalisation is associated with the development of ties with firms in foreign markets. For Weerawardena et al. (2007), the internationalisation is influenced by dynamic capacities focused on learning, marketing and networking. Coviello (2006) also considers that the internationalisation of innovative SMEs is reinforced by the relationships that will be established to do business.

The internationalisation is strongly associated with the founder's abilities. If they meet some criteria; they will be able to identify and exploit international opportunities and also use any contacts they may have in foreign markets efficiently (McDougall et al., 1994). They also develop international relationships during their studies abroad and from their previous international work experience (Crick and Jones, 2000). In case the entrepreneur does not have initially international contacts, his best strategy would be to avoid more competitive markets in favour of less exploited and less lucrative ones. Moreover, some firms tend to engage business development officers which may include heavy or important cash flows. This alternative approach seems to be in its infancy and its effectiveness remains uncertain at this stage. In addition, Prashantham (2006) emphasises that the network can provide richness in opportunities and potential binding.

In short, it seems to us that international positioning in a niche market as well as the export capacity is convergent criteria between entrepreneurship, innovative SMEs and networking. This led us to the following conclusion, exporting is therefore not only based on an intensive effort linked to innovation, it is also necessary to look at the relationships that the entrepreneur can establish with actors in his environment and abroad.

H2 International networking affects exporting positively.

\subsection{The effect of society culture on the export's share in the firm 's business structure}

Societal norms may influence individual behaviour through the values and attitudes considered to be socially acceptable (Ross and Nisbett, 1991). Culture is the interactive aggregate of common characteristics that influence a human group's response to its environment. It is a collective mental programming, it is the average of the beliefs and values of individuals who live in a country and it determines the identity of a human group in the same way personality determines the identity of an individual (Hofstede, 1980). With an individual, personality influences the choices made and the resulting outcomes. Culture similarly shapes the society according to several structures (McGrath et al., 1992b). The concept of national character is a model for showing the personality characteristics of each nation. Since the 1930s, two types of studies dealing with the national character have multiplied: first, cross-cultural studies which aim to identify similarities and differences between nations. Second, studies on the national character which aim to characterise national behaviour through a range of phenomena. Benedict in 1934 showed that the personality of the individual and the group (firm for example) is configured by cultural factors. Numerous authors have conducted cross-cultural studies to create national reading grids and to understand cultural differences. Each culture will 
shape the behaviour of individuals to respond to problems that depend on national character (Hills, 2002). The Hofstede reading grid developed in 1980 describes the main cultural dimensions that differentiate human groups and showed the consequences that result in the areas of human management, in the way they are led, motivated and organised. The main idea is to refute that differences between management in different countries tend to disappear as a result of the application of universal management principles. In the case of management, nationality is important for at least three types of reasons:

- Politics: nations are political entities with their own institutions. Comparatively official institutions differ as well as the way they are used.

- Sociological: belonging to a country or region has a symbolic value that partially defines identity.

- Psychological: the national culture partly defines our thinking. It is an effect of the experience acquired since childhood within the family, then from education at school and in institutions, which are not the same from one country to another.

Table 1 Key characteristics of individualism and collectivism

\begin{tabular}{lcc}
\hline & Individualism & Collectivism \\
\hline Goals & Self-oriented & Group-oriented \\
Values & Short-term & Long-term \\
& Achievement & Pro-social \\
& Self-direction & Conformity \\
& Social power & Security \\
Relationships & Stimulation & Tradition \\
& Debate, confrontation acceptable & Harmony required \\
& Conflict accepted, but not desired & Conflict expected \\
Attributions & Many loose ties & Few close links \\
& Success due to ability & Success from group effort \\
& Failure from external factors & Failure due to lack of effort
\end{tabular}

Source: Tiessen (1997)

Countries are often characterised as individualistic or collectivist. However, it must be understood that each country is imbued to a different degree with these two dimensions (Oyserman et al., 2002). Individualism and collectivism represent the psycho-social relationships of the individual and the group at the societal level. The measurement of individualism or collectivism in societies contains specific features of each pole (Hamamura, 2012). Individualists focus on personal achievement and the ability to perform tasks alone in order to achieve their goals (Hofstede, 1980). Exporting seems to be one of the most effective ways for entrepreneurs to prove themselves (Bai et al., 2017).

On the other hand, in so-called collectivist societies, the goals and values of individuals are polarised in contrast to those of individualistic societies. In fact, "the individuals from a collectivist culture see themselves as interdependent within their group, which provides them with a stable social environment to which they must adapt. 
Their personalities are flexible and their personal traits are not so clear" (Cozma, 2011). In general, collectivist societies are based on mutual bonds that are based on values and common goals that are central to the achievement of happiness for all. The individual then becomes a part of the group in the context of collectivism (Triandis, 2001). It has been shown that a country's national culture has an impact on an entrepreneur's international strategic decisions and choices (Leung et al., 2005).

Another aspect of individualism is the importance of rewarding people for efforts above those of others. In individualistic societies, people believe in the importance of rewarding success through recognition and financial compensation, but in collectivist societies these rewards are less socially acceptable (Shane, 1992). The values of the individualistic society: achievement; self-direction and stimulation are personality traits commonly associated with entrepreneurship, entrepreneurial success and business growth (Delmar and Wiklund, 2003; Swierczek and Thanh Ha, 2003). Similarly, numerous studies have shown that motivation for achievement is linked to autonomy and risk taking (Swierczek and Thanh Ha, 2003).

H3 The more individualistic a society is, the more it promotes export.

Individualism/collectivism refers to the relationship between individuals. Thus, the links range from very loose (we look after our close interests) to very strong (we look after the interests of the group). Individualistic societies are societies in which the ties between individuals are weak, everyone is expected to take care of themselves and their immediate families, while in collectivist society's people, from birth, are integrated into groups with strong and coherent ties that, throughout their lives, continue to protect them in exchange for unfailing loyalty. Rewards of highly individualistic societies are couched in such terms as autonomy, pleasure, and financial security, rather than order, duties, and security through social relationships (McGrath et al., 1992a).

Moreover, innovation is based on the creation of new concepts because the identification of new concepts requires innovative thinking and action, while resource leverage requires effective implementation: optimal usage of the resources provided by social capital involves promoting relationships through open communication and coordination. Therefore, trends in these behaviours depend on different types of cultural orientations (Tiessen, 1997). The quality of the network and social capital depends on the economic and cultural capital of the individual and is the result of his social investment whether he is conscious or not. In this sense, social capital is an asset that the individual can maintain, influence and develop through a willingness to acquire and maintain relationships and connections, which implies a permanent expenditure of time and effort (Bourdieu, 1980), a constraint that Burt (1995) considers depending on the size of the network, its density and its hierarchy. Collectivism promotes more harmonious relations between individuals. The combined efforts of people with diverse skills in collectivist societies can lead to greater synergies, while individuals can benefit from a social support network (Morris et al., 1994).

H4 The more individualistic a society is, the less the entrepreneur benefits from the advantages of his own international network. 


\section{Data and methodology}

\subsection{Sampling}

The Global Entrepreneurship Monitor (GEM) consortium conducts two surveys per year with two different targets. The first one is the GEM Adult Population Survey, which provides standardised data on the preferences, capacities and entrepreneurial activities of each population. The second one is the National Expert Survey, in which specialists and experts from each country participating in the survey give their appreciation of several framework conditions for entrepreneurship in their respective countries. These experts are also asked about the entrepreneurial opportunities and capacities of their country (Sternberg and Wennekers, 2005). The basic model utilised to develop the GEM research program envisioned characterisation of countries in terms of nine dimensions, referred to as entrepreneurial framework conditions. The entrepreneurial framework conditions would represent different aspects of the national context that were expected to enhance entrepreneurial activity (Reynolds et al., 2005).

The adult population survey adopted questions for owner managers on their social network, the degree of the firm's innovation and the share of production oriented to export. The national expert survey asked questions about socio-cultural norms in each country, which made it possible to identify the level of individualism of the societies in question. From the entire sample from different countries in the MENA region, we extracted a subsample by selecting observations that provided information on the international network of owner-managers. The observations came from about 15 countries and covered the period 2009-2014. The population survey gives us the possibility to isolate 8,605 active firms, for which there is no lack of data on the variables used in the analysis (Table 3 ).

This study focuses on countries selected primarily by self-selection, techniquely designed through researchers from one country adhesion to the GEM program. The firms in the sample come from the following countries: Algeria, Egypt, Iran, Jordan, Lebanon, Libya, Morocco, Pakistan, Palastin, Qatar, Saudi Arabia, Syria, Tunisia, Turkey, and UAE. These countries are fairly representative of the entire Middle East and North Africa region, as well as the sampling in each country is random. We believe that the results from this sample can be generalised to all countries in the MENA region.

\subsection{Variables specification}

\subsubsection{Endogenous variable}

The dependent variable used to calculate the foreign market openness strategy is export level, which is defined by the share of customers living abroad compared to the global customers population of each firm. The following question was administered to owner managers.

"What proportion of your customers will normally live outside your country? Is it more than $90 \%$, more than $75 \%$, more than $50 \%$, more than $25 \%$, more than $10 \%$, or $10 \%$ or less?"

It is a categorical variable that can take unit values from 1 to 7.1 for none and 7 for more than $90 \%$ (Table 3 ). 


\subsubsection{Exogenous variables}

\subsubsection{GEM's innovation measurement}

Our study focuses on the hypothetical role of innovation in determining the level of exports. To determine the degree of innovation of a firm, the GEM adult populations survey collected answers to the following three questions:

- Have the technologies or procedures required for this product or service been available for less than a year, or between one and five years, or longer than five years?

- Do all, some, or none of your potential customers consider this product or service new and unfamiliar?

- Right now, are there many, few, or no other businesses offering the same products or services to your potential customers?

The answer to each question is given on a scale of 1 to 3 points interpreted as a low, medium and high innovation degree. Entrepreneurs differ from each other in every dimension. We use as a proxy to measure firms degree of innovation, the question's answer average as explained above.

\subsubsection{International networking}

The GEM survey has dedicated a whole block of questions treating the social capital concern, we've selected two questions presented below, since they are the only ones to define the owner manager's international network.

- Various people may give you advice on your business. During the last year, have you received advice from somebody in another country?

- Various people may give you advice on your business. During the last year, have you received advice from somebody who has come from abroad?

The two questions are dichotomous, taking binary values, 1 if the answer is confirmed or 0 if it is declined. We use as a proxy to measure firms international networking, the previously presented question's answer average. Table 4 presents the distribution of firms by international networks.

\subsubsection{Society's individualism level}

The GEM survey, for the evaluation of the national framework, asked the experts to assess several entrepreneurship conditions, including cultural and social norms. National experts were selected on the basis of their deep knowledge of entrepreneurship in their country. In general, experts were identified among entrepreneurs, consultants, academics, but also politicians or administrators. The experts decided on five statements describing cultural and social norms in their respective countries using a Likert scale ranging from $1=$ completely false to $5=$ completely true.

The average of the evaluations was calculated for all experts, for the five statements and for all years to obtain a measure of quality in the country. 
The following five statements were the subject of the experts' judgment in order to determine the score awarded to assess cultural and social norms:

- The national culture values individual success that results from personal efforts.

- The national culture emphasises self-sufficiency, autonomy and individual initiative.

- The national culture encourages entrepreneurial risk taking.

- National culture encourages creativity and innovation.

- National culture values individual (rather than collective) responsibility in the way one conducts one's life.

\subsubsection{Control variables}

In order to properly identify the predictive effect of innovation and the owner manager's international network on the firm's exports, our model will test a set of control variables.

Table 2 Control variables

\begin{tabular}{|c|c|}
\hline Gendre & Code 1 if the owner manager is a female and 0 if it's otherwise \\
\hline \multirow{2}{*}{$\begin{array}{l}\text { Growth } \\
\text { expectations }\end{array}$} & The expected evolution of employees over the next five years \\
\hline & $\begin{array}{l}\text { Calculated like this: logarithm (jobs in } 5 \text { years }+1)- \text { logarithm (now jobs }+ \\
\text { 1) }\end{array}$ \\
\hline Age & Logarithm of the owner-manager's age \\
\hline Opportunity & The dichotomous variable coded 1 if recognising opportunity and 0 if not \\
\hline Education & Logarithm of the number of years the owner manager spend at school \\
\hline Self-efficacy & $\begin{array}{l}\text { Dichotomous variable, } 1 \text { indicates the owner manager's confidence in his } \\
\text { own ability to start and operate a business, } 0 \text { if he has a lack of confidence }\end{array}$ \\
\hline Risk propensity & Coded 1 if the owner manager does not fear failure and 0 if he does \\
\hline Firm age & Logarithm of the number of years of activity plus 1 \\
\hline $\begin{array}{l}\text { Know } \\
\text { entrepreneur }\end{array}$ & $\begin{array}{l}\text { Dichotomous variable coded } 1 \text { if knowing someone personally who started a } \\
\text { business in the past } 2 \text { years and } 0 \text { if not }\end{array}$ \\
\hline Workforce size & Logarithm of the number of employees plus 1 \\
\hline
\end{tabular}

\subsection{The hierarchical linear model}

Exporting is the result of a multidimensional and interactive set of factors, including the economic and business environment, market structure, market opportunities and strategies. Exporting is often riskier than targeting the domestic market. Export entrepreneurs must therefore be particularly skilled and sell products that are profitable and attractive. It seems important in this regard that the entrepreneur should be creative in the application and the eventual commercialisation of the new technologies, he must also be familiar with foreign markets and foreign business environments, and be well positioned in order to be distinguished in his trade and label, thereby reducing the ability of competitors to enter the market (Jones and Way, 2011).

Our study takes into consideration the firms and their evolution in a given context. We hereby seek to highlight the specific firm's characteristics and their national conditions which determine their exports level. Two levels of analysis were adopted to 
achieve the goal of our study, the first level of analysis was the country approximated by one variable which is the degree of society individualism, and the second one focuses on the firms, which was approximated by the whole other variables.

A multiple linear regression presents many limits and is not the best technique to address the issue of our model: first of all, it does not allow for context effects to be taken into consideration. Second of all, our sample is not a monolithic group of firms, but several different subgroups from each country, those differences represent the specificities of each society captured by the GEM experts' survey, knowing that each country will have a designated value measuring the degree of society individualism and systematically this unique value will be associated with a subgroup of firms from the same country, this may end by causing a selection bias eventually. In this case a hierarchical linear model is more appropriate (Gelman and Hill, 2006). We will use linear mixed effects modelling as it gives us the opportunity to get the most out of the information and correct problems related to disproportionate groups $(8,605$ firms clustered within 15 countries). Our study, then, can be schematised according to the conceptual framework (Figure 1).

Figure 1 Conceptual model

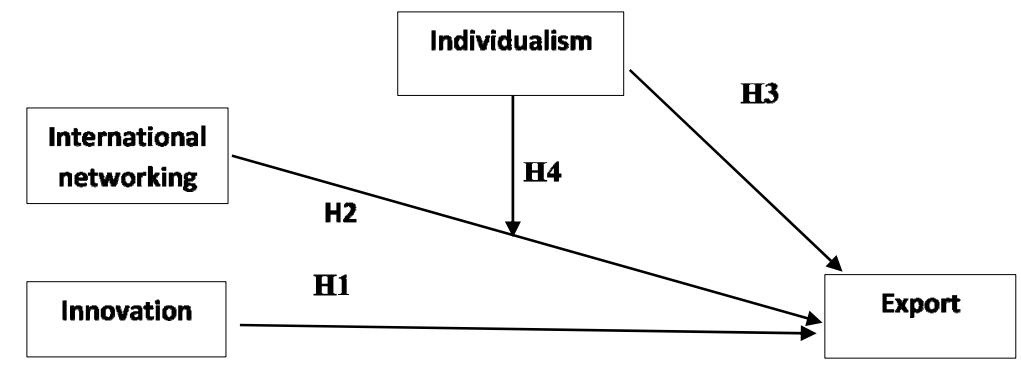

\section{Results}

\subsection{Means and correlations}

The correlation between the variables, including the firm's export level, is presented in Table 3 .

All variables are significantly correlated except 'gender' and 'risk taking'.

All correlations are not at a high level, the strongest correlation is observed between the log firm's age and international networking $(-0.423)$. Since there is some correlation among the explanatory variables, a multicollinearity test was undertaken. As a consequence, we used the variance inflation factor (VIF) test. The VIF shows us how much the variance of the coefficient estimate is inflated by multicollinearity: VIF of 10 or higher may be a reason for concern. As shown in Table 3, no variable has a VIF higher than 10; therefore no relevant multicollinearity is found between variables (max $\mathrm{VIF}=1,496)$. 
Table 3 Means, standard deviations and correlations $(\mathrm{N}=8,605$ firms $)$

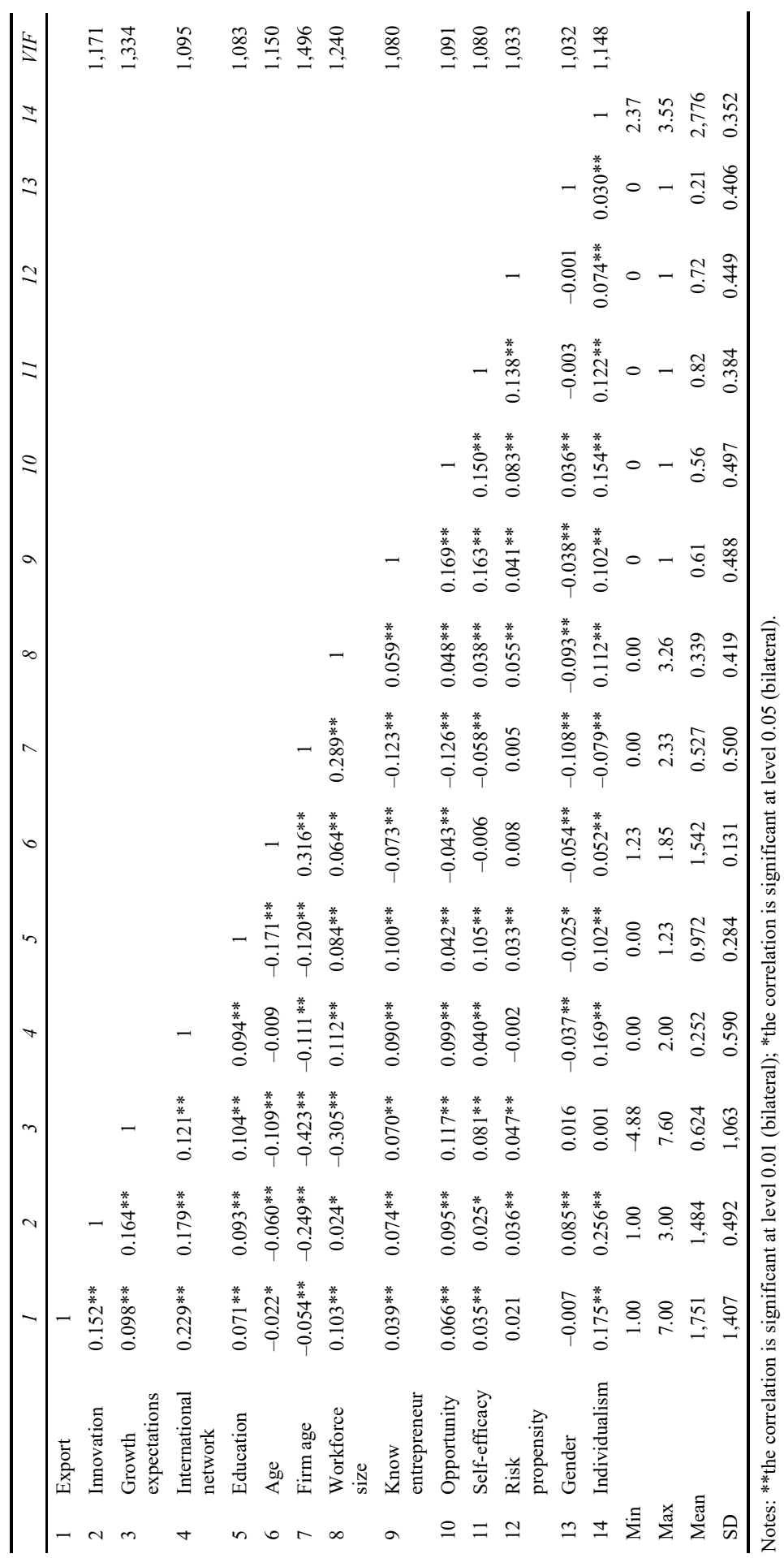




\subsection{Statistical approach}

\subsubsection{Exporting level}

The first observation that comes to mind after reading Table 4 seems to be less than one third of the firms are exporters. Almost half of those exporters have an export level that does not exceed $10 \%$. We also observe that the number of firms with more than $90 \%$ of their customers living abroad is very low compared to firms that do not export (Table 4) which explains a mean level of exports by MENA firms of 1,751 (Table 3).

Table 4 Distribution of sampled firms

\begin{tabular}{lccc}
\hline Exporting level & Code & Firms & $\%$ \\
\hline None & 1 & 5,768 & 67.03 \\
Under 10 & 2 & 1,392 & 16.17 \\
10 to $24 \%$ & 3 & 419 & 4.87 \\
25 to $49 \%$ & 4 & 404 & 4.7 \\
50 to $74 \%$ & 5 & 291 & 3.38 \\
75 to $90 \%$ & 6 & 125 & 1.45 \\
More than $90 \%$ & 7 & 206 & 2.4 \\
Total & & 8,605 & 100 \\
\hline
\end{tabular}

\subsubsection{Innovation in MENA's firms}

The distribution of the innovation represents an asymmetry coefficient equal to 0.791 and positive indicates a distribution shifted to the left of the median which equals 1,333 , and therefore a distribution tail spread to the right. Most entrepreneurs report a lack of innovation and few have a high level of innovation, only slightly more than $10 \%$ have an innovation above the average Table 5.

Table 5 Firms' level of innovation

\begin{tabular}{lcc}
\hline & Frequency & $\%$ \\
\hline Low level of innovation & 6,561 & 76.25 \\
Medium level of innovation & 1,128 & 13.11 \\
High level of innovation & 916 & 10.64 \\
Total & 8,605 & 100.0 \\
\hline
\end{tabular}

\subsubsection{International networking}

Analysis of the owner-manager's international networking data allows us to note that the number of firms fortunate enough to receive advice from people knowledgeable about foreign markets is low. International networking appears to be the independent variable with the highest correlation with the firm's export level (Table 3).

\subsubsection{Individualism}

Individualism is higher in the UAE with a value of 3.55 and lower in Iran with a value of 2.37. This measure of socio-cultural norms is used to analyse the effects of individualism 
on the level of exports and its moderator effect on international networking (Table 7). The mean of individualism value according to the survey is 2.77 (Table 3 ).

Table 6 Owner manager's international network

\begin{tabular}{lcc}
\hline & Frequency & $\%$ \\
\hline No advice from abroad & 7,124 & 82.79 \\
Low-level advice from abroad & 792 & 9.20 \\
High level of advice from abroad & 689 & 8.01 \\
Total & 8,605 & 100.0 \\
\hline
\end{tabular}

Table 7 Sampled countries by individualism-level

\begin{tabular}{lc}
\hline Country & Society's individualism level \\
\hline UAE & 3.55 \\
Lebanon & 3.43 \\
Algeria & 3.12 \\
Egypt & 2.39 \\
Morocco & 2.39 \\
Iran & 2.37 \\
\hline
\end{tabular}

\subsection{Econometric approach}

\subsubsection{Modelling the effects of innovation, international networking and individualism}

Hypotheses 1, 2 and 3 are tested by two-level linear modelling, as described in Table 8 . The results of the first modelling are as it follows: our first hypothesis states that the firm's level of export is positively influenced by the level of innovation (taking into account innovations incorporated in the product, and the processes or perceived by customers). In the linear model detailed in Table 8 , the effects of the different variables are estimated by coefficients. It shows that innovation has a positive impact on the level of exports, which confirms the first hypothesis. The more innovative a firm is, the higher the share of exports in its sales. This remains true even if many other variables (control variables) are taken into account. Innovations offer sustainable competitive advantages that give firms the opportunity to launch and/or expand their exports and to be more proactive and innovative in competing in different markets.

The same result has been registered for the owner manager's international network effect, which confirms Hypothesis 2. Society's individualism level has a positive effect on the firm's exports level, which confirms Hypothesis 3 (Table 8). The positive coefficient states that entrepreneurs who live and are influenced by an environment marked by a high level of individualism that values autonomy, personal interests and the quest for self-realisation are more export-oriented than entrepreneurs from more collectivist environments. The individualism of the society is a determinant of export levels. 
Table 8 Firms' exporting level affected by Innovation, international network and individualism

\begin{tabular}{lc}
\hline & Metric coefficient \\
\hline Intercept & 0.111 \\
Innovation & $0.213^{* * *}$ \\
International network & $0.379^{* * *}$ \\
Growth expectations & $0.148^{* * *}$ \\
Education & $0.153^{* *}$ \\
Age & -0.209 \\
Firm age & 0.069 \\
Workforce size & $0.318^{* * *}$ \\
Know entrepreneur & -0.006 \\
Opportunity & 0.001 \\
Self-efficacy & -0.043 \\
Individualism & $0.458^{*}$ \\
\hline
\end{tabular}

Notes: Based on 15 countries with 8,605 entrepreneurs; *p $<0.05 ; * * p<0.01$; $* * * \mathrm{p}<0.001$.

\subsubsection{The effect of the socio-cultural context on the level of exports}

According to Hypothesis 4, individualism reduces the effect of the owner-manager's international network, i.e., a context that places greater value on risk taking, individualism, autonomy, creativity and innovation reduces the effect of international networking. The moderating influence is modelled as an interaction effect; we simply include the interaction or the combination of the cited variables: Individualism and international networking in the two-level linear model already obtained (Table 9).

Table 9 Moderating effect of individualism on innovation

\begin{tabular}{lc}
\hline & Metric coefficient \\
\hline Intercept & -0.225 \\
Innovation & $0.211^{* * *}$ \\
International network & $1,331^{* * *}$ \\
Growth expectations & $0.147^{* * *}$ \\
Education & $0.155^{* *}$ \\
Age & -0.199 \\
Firm age & 0.064 \\
Workforce size & $0.322^{* * *}$ \\
Know entrepreneur & -0.005 \\
Opportunity & -0.001 \\
Self-efficacy & -0.043 \\
Individualism & $0.574 * *$ \\
Individualism * international network & $-0.329 * * *$ \\
\hline
\end{tabular}

Notes: Based on 15 countries with 8,605 entrepreneurs; *p $<0.05 ; * * p<0.01$; $* * * \mathrm{p}<0.001$. 
The results obtained confirm Hypothesis 4, the moderator variable 'individualism' is associated with a negative coefficient to 'international networking' with a significant $\mathrm{P}$ value which is less than 0.05 .

The model allows us to estimate the importance of individualism in mitigating the effect of the owner-manager's international network. We can compare the effect between a country where individualism level is low and the same effect in a country where the individualism level is high. Individualism undermines the quality of social relationships and what may occur as benefits from them. We take individualism extreme score cases: 2.37 and 3.55 (respectively the scores of Iran and UAE).

$$
\begin{aligned}
\text { Export level } & =-0.225+0.211 \text { innovation }+1,331 * \text { international network } \\
& +0.574 \text { societies' individualism level }-0.329 \text { individualism's level } \\
& * \text { international network }+0.147 \text { growth expectations } \\
& +0.155 \text { education }+0.322 \text { workfore size }+\ldots
\end{aligned}
$$

- The Iranian context: The model output can be expressed as follows:

Export level $=0.211$ innovation $+1,331 *$ international network

$+0.574 *$ societies' individualism level $-0.329 * 2.37$

$*$ international network $+0.15 *$ growth expectations

+etc. as in Table 9

The effect of the owner-manager's international network on the level of export is expressed as:

Export level $=0.211$ innovation $+0.551 *$ international network

+etc. as in Table 9.

- The Emirati context: The model output can be expressed as follows:

Export level $=0.211$ innovation $+1,331 *$ international network

$+0.574 *$ societies' individualism level $-0.329 * 3.55$

*international network $+0.15 *$ growth expectations

+etc. as in Table 9

The effect of the owner-manager's international network on the level of export is expressed as:

$$
\begin{aligned}
\text { Export level } & =0.211 \text { innovation }+0.163 * \text { international network } \\
& + \text { etc. } \text { as in Table } 9 .
\end{aligned}
$$

Obviously, it seems that owner manager's international network effect in the Emirat's context is $70.42 \%$ less important, compared to the same effect in the Iranian's context.

\section{Discussion}

Our model shows the positive effect of innovation on the level of firms' exports, so our results are supported by previous research (Caldera, 2010; Filipescu et al., 2013; Jensen 
and Schott, 2015; Lachenmaier and Wößmann, 2006; Pla-Barber and Alegre, 2007). The authors confirm the innovation-export causality in Western countries. Our study extends this finding to the MENA region, and it is in a perfect alignment with the studies mentioned above and confirms the positive effect of innovation on business exports implemented on a large sample from 15 eastern developing countries (Table 10).

Table 10 Our results in comparison with past studies

\begin{tabular}{|c|c|c|}
\hline Study and sample & Result & Our results \\
\hline $\begin{array}{l}\text { Spain, Panel 1991-2002: } \\
\text { 21,949 observations } \\
\text { (Caldera, 2010) }\end{array}$ & $\begin{array}{l}\text { - Innovation impacts positively export } \\
\text { - Firm age positively linked to export level } \\
\text { - Firm size nositively linked to exnort level }\end{array}$ & $\begin{array}{l}\text { Our study showed } \\
\text { a positive } \\
\text { relationship } \\
\text { between firm size }\end{array}$ \\
\hline $\begin{array}{l}\text { Spain, Panel 1994-2005: } \\
8,297 \text { observations } \\
\text { (Filipescu et al., 2013) }\end{array}$ & $\begin{array}{l}\text { - Process innovation positively affects export } \\
\text { - Firm size is not significantly linked to export } \\
\text { - Firm age positively linked to export level }\end{array}$ & $\begin{array}{l}\text { and export, but } \\
\text { not significant one } \\
\text { for firm age }\end{array}$ \\
\hline $\begin{array}{l}\text { Germany, The } 2002 \text { Ifo } \\
\text { Innovation Survey: } 981 \\
\text { firms (Lachenmaier and } \\
\text { Wößmann, 2006) }\end{array}$ & $\begin{array}{l}\text { - Innovation and expenditure on innovation } \\
\text { have a positive impact on the level of exports } \\
\text { - Firm size is not significantly linked to export }\end{array}$ & \\
\hline $\begin{array}{l}\text { French 2002: } 121 \text { firms } \\
\text { (Pla-Barber and Alegre, } \\
\text { 2007) }\end{array}$ & $\begin{array}{l}\text { - Innovation impacts positively export level } \\
\text { - Firm size positively linked to export level }\end{array}$ & $\begin{array}{l}\text { Our results } \\
\text { corroborate those }\end{array}$ \\
\hline $\begin{array}{l}8,918 \text { start-up firms in } 40 \\
\text { countries GEM 2012-2013 } \\
\text { (Jensen and Schott, 2015) }\end{array}$ & $\begin{array}{l}\text { - Innovation impacts positively export level } \\
\text { - Network positively affects export level }\end{array}$ & of the study \\
\hline
\end{tabular}

We have shown the role of the social network on the firm's export share. The entrepreneur's ability to create a network of contacts is essential (networking skills). The international network of entrepreneurs operates at several levels. For example, it can be used to obtain information on foreign markets. It sometimes acts as an intermediary to access potential customers. Finally, it plays a major role to develop various strategies used to penetrate foreign markets.

There is a very thin literature confirming the effect of the network on firms' enhancing export's shares, our study shows this causality for a specific type of network especially international networking (Ashourizadeh et al., 2014). We were able to show the importance of the international network for firms in the MENA region to determine export levels. Similarly, we have highlighted the influence of the society's individualism level, a deterministic effect. We have obtained a positive effect on the firm's exports level, the variable distinguishes between societies according to their individualism degree. Individualism, which is considered to be a driving force for entrepreneurship and success, has a positive influence on exports. This paper shows the impact of context and environment on organisational behaviour at an individual level (firm). If individualism eases entrepreneurship and creates a competitive spirit, from one point of view, it undermines the quality of the relationship that the entrepreneur can have from a second point of view. This is confirmed in our model by the negative moderating effect that society's individualism level has on the owner manager's international network. The network positive effect initially observed is greatly reduced by taking into account its interaction with the societies individualism level. 


\section{Conclusions}

This study examined the different effects of innovation, entrepreneur's international network and environment on the export's level. We focused on answering the following question: how innovation and entrepreneur's international network influence export's level? Although there has been a growing recognition of the role of innovation and network on the internationalisation of firms, very few empirical studies correlate these three dimensions, and we've tried modestly to contribute to covering this gap by a theoretical framework compilation which was tested in this research.

We have tested four hypotheses, the first one is about innovation and its positive impact on helping firms to be more export oriented, and in a better position to distinguish themselves in the foreign market. The second one is the entrepreneur's international network that may influence positively research and evaluation of foreign markets opportunities. The third one is the impact of the environment on export's level. The last one is the interaction between environmental impact and international networking. To test these hypotheses, the study built on quantitative data collected from the GEM using a sample of 8,605 firms from 15 countries. The main results were expected and led to understand and explain the correlation between the combination innovation networking and export level.

Researchers emphasised the need to clarify the sense of causality between innovation and exports. Moreover, innovation, knowledge and capabilities are central themes in research on international strategy and business performance. However, to maintain their competitive advantage, firms must learn from their activities in international markets and translate this knowledge into more innovations that better meet the changing needs of domestic and international consumers. Innovation and exports are complementary activities that reinforce each other (Filipescu et al., 2013; Golovko and Valentini, 2011). Therefore, in our study, we argue that resources and innovation can influence exports. The question of causality between innovation and exports is only half resolved. The reverse link, the influence of exports on innovation in exporting firms, remains to be verified, especially in MENA countries.

\section{References}

Altomonte, C., Aquilante, T., Békés, G. and Ottaviano, G.I. (2013) 'Internationalization and innovation of firms: evidence and policy', Economic Policy, Vol. 28, No. 76, pp.663-700.

Ashourizadeh, S., Rezaei, S., Schott, T. and Vang, J. (2014) 'Entrepreneurs' human and social capital: direct and reinforcing benefits for export', International Journal of Entrepreneurship and Small Business, Vol. 21, No. 2, pp.246-267, DOI: 10.1504/ijesb.2014.059476.

Aw, B.Y., Roberts, M.J. and Xu, D.Y. (2008) 'R\&D investments, exporting, and the evolution of firm productivity', American Economic Review, Vol. 98, No. 2, pp.451-456.

Bai, X., Krishna, K. and Ma, H. (2017) 'How you export matters: export mode, learning and productivity in China', Journal of International Economics, January, Vol. 104, No. 1, pp.122-137.

Baker, W.E., Grinstein, A. and Harmancioglu, N. (2016) 'Whose innovation performance benefits more from external networks: entrepreneurial or conservative firms?', Journal of Product Innovation Management, Vol. 33, No. 1, pp.104-120.

Becker, S.O. and Egger, P.H. (2013) 'Endogenous product versus process innovation and a firm's propensity to export', Empirical Economics, Vol. 44, No. 1, pp.329-354. 
Boso, N., Story, V.M., Cadogan, J.W., Micevski, M. and Kadić-Maglajlić, S. (2013) 'Firm innovativeness and export performance: environmental, networking, and structural contingencies', Journal of Marketing Research, Vol. 21, No. 4, pp.62-87.

Bourdieu, P. (1980) 'Le capital social: notes provisoires', Actes de la Recherche en Sciences Sociales, Vol. 31, No. 1, pp.2-3.

Bravo-Ortega, C., Benavente, J.M. and González, Á. (2014) 'Innovation, exports, and productivity: learning and self-selection in Chile', Emerging Markets Finance and Trade, Vol. 50, No. Sup. 1, pp.68-95.

Burt, R.S. (1995) 'Le capital social, les trous structuraux et l'entrepreneur', Revue Française de Sociologie, Analyses de Réseaux et Structures, Vol. 36, No. 4, pp.599-628.

Bustos, P. (2011) 'Trade liberalization, exports, and technology upgrading: evidence on the impact of MERCOSUR on Argentinian firms', American Economic Review, Vol. 101, No. 1, pp.304-340.

Caldera, A. (2010) 'Innovation and exporting: evidence from Spanish manufacturing firms', Review of World Economics, Vol. 146, No. 4, pp.657-689.

Cassiman, B., Golovko, E. and Martínez-Ros, E. (2010) 'Innovation, exports and productivity', International Journal of Industrial Organization, Vol. 28, No. 4, pp.372-376.

Chetty, S. and Holm, D.B. (2000) 'Internationalisation of small to medium-sized manufacturing firms: a network approach', International Business Review, Vol. 9, No. 1, pp.77-93.

Coleman, J.S. (1988) 'Social capital in the creation of human capital', American Journal of Sociology, Vol. 94, pp.S95-S120.

Coviello, N.E. (2006) 'The network dynamics of international new ventures', Journal of International Business Studies, Vol. 37, No. 5, pp.713-731.

Cozma, I. (2011) 'How are individualism and collectivism measured', Romanian Journal of Applied Psychology, Vol. 13, No. 1, pp.11-17.

Crick, D. and Jones, M.V. (2000) 'Small high-technology firms and international high-technology markets', Journal of International Marketing, Vol. 8, No. 2, pp.63-85.

Delmar, F. and Wiklund, J. (2003) 'Growth motivation and growth: untangling causal relationships', Academy of Management Best Conference Paper 2003 ENT.

Deng, Z., Guo, H., Zhang, W. and Wang, C. (2014) 'Innovation and survival of exporters: a contingency perspective', International Business Review, Vol. 23, No. 2, pp.396-406.

Dubini, P. and Aldrich, H. (1991) 'Personal and extended networks are central to the entrepreneurial process', Journal of Business Venturing, Vol. 6, No. 5, pp.305-313.

Eaton, J. and Kortum, S. (2002) 'Technology, geography, and trade', Econometrica, Vol. 70, No. 5, pp.1741-1779.

Filipescu, D.A., Prashantham, S., Rialp, A. and Rialp, J. (2013) 'Technological innovation and exports: unpacking their reciprocal causality', Journal of International Marketing, Vol. 21, No. 1, pp.23-38.

Gaussens, O. and Movahedi, M. (2015) 'Les effets de l'exportation sur l'innovation et la productivité: le rôle clef de l'apprentissage par l'exportation analyse empirique sur un échantillon de PMI', Revue Internationale PME, Vol. 29, No. 1, pp.101-141.

Gelman, A. and Hill, J. (2006) Data Analysis using Regression and Multilevel/Hierarchical Models, Cambridge University Press, Cambridge, Analytical Methods for Social Research, doi: $10.1017 / \mathrm{CBO} 9780511790942$.

Golovko, E. and Valentini, G. (2011) 'Exploring the complementarity between innovation and export for SMEs' growth', Journal of International Business Studies, Vol. 42, No. 3, pp.362-380.

Grossman, G.M. and Helpman, E. (1989) 'Product development and international trade', Journal of Political Economy, Vol. 97, No. 6, pp.1261-1283.

Grossman, G.M. and Helpman, E. (1991) 'Quality ladders and product cycles', The Quarterly Journal of Economics, Vol. 106, No. 2, pp.557-586. 
Hamamura, T. (2012) 'Are cultures becoming individualistic? A cross-temporal comparison of individualism-collectivism in the United States and Japan', Personality and Social Psychology Review, Vol. 16, No. 1, pp.3-24.

Hills, M.D. (2002) 'Kluckhohn and Strodtbeck's values orientation theory', Online Readings in Psychology Culture, Vol. 4, No. 4, p.3.

Hofstede, G. (1980) Culture's Consequences: International Differences in Work-Related Values, Sage Publications, Beverly Hills.

Jensen, K.W. and Schott, T. (2015) 'Start-up firms' networks for innovation and export: facilitated and constrained by entrepreneurs' networking in private and public spheres', Social Network Analysis Mining, Vol. 5, No. 1, p.48.

Jiménez-Guerrero, J.F., Pérez-Mesa, J.C., de Burgos-Jiménez, J. and Piedra-Muñoz, L. (2018) 'Considering the consumer in the design of a supply chain of perishables', International Food and Agribusiness Management Review, Vol. 21, No. 4, pp.525-542.

Johanson, J. and Mattsson, L. (1988) 'Internationalisation in industrial systems - a network approach', in Strategies in Global Competition, pp.287-314, Croom-Helm, New York.

Jones, K. and Way, M. (2011) Entrepreneurship and the Decision to Export. The Dynamics of Entrepreneurship. Evidence from Global Entrepreneurship Monitor Data, pp.277-298, Oxford Scholarship Online, September, DOI: 10.1093/acprof:oso/9780199580866.001.0001.

Lachenmaier, S. and Wößmann, L. (2006) 'Does innovation cause exports? Evidence from exogenous innovation impulses and obstacles using German micro data', Oxford Economic Papers, Vol. 58, No. 2, pp.317-350.

Leung, K., Bhagat, R.S., Buchan, N.R., Erez, M. and Gibson, C.B. (2005) 'Culture and international business: recent advances and their implications for future research', Journal of International Business Studies, Vol. 36, No. 4, pp.357-378.

Love, J.H. and Roper, S. (2015) 'SME innovation, exporting and growth: a review of existing evidence', International Small Business Journal, Vol. 33, No. 1, pp.28-48.

Máñez-Castillejo, J.A., Rochina-Barrachina, M.E. and Sanchis-Llopis, J.A. (2009) 'Self-selection into exports: productivity and/or innovation?', Applied Economics Quarterly, Vol. 55, No. 3, p.219.

McDougall, P.P., Shane, S. and Oviatt, B.M. (1994) 'Explaining the formation of international new ventures: the limits of theories from international business research', Journal of Business Venturing, Vol. 9, No. 6, pp.469-487.

McGrath, R.G., MacMillan, I.C. and Scheinberg, S. (1992a) 'Elitists, risk-takers, and rugged individualists? An exploratory analysis of cultural differences between entrepreneurs and non-entrepreneurs', Journal of Business Venturing, Vol. 7, No. 2, pp.115-135.

McGrath, R.G., MacMillan, I.C., Yang, E.A-Y. and Tsai, W. (1992b) 'Does culture endure, or is it malleable? Issues for entrepreneurial economic development', Journal of Business Venturing, Vol. 7, No. 6, pp.441-458.

Monreal-Pérez, J., Aragón-Sánchez, A. and Sánchez-Marín, G. (2012) 'A longitudinal study of the relationship between export activity and innovation in the Spanish firm: the moderating role of productivity', International Business Review, Vol. 21, No. 5, pp.862-877.

Morris, M.H., Davis, D.L. and Allen, J.W. (1994) 'Fostering corporate entrepreneurship: cross-cultural comparisons of the importance of individualism versus collectivism', Journal of International Business Studies, Vol. 25, No. 1, pp.65-89.

Oyserman, D., Coon, H.M. and Kemmelmeier, M. (2002) 'Rethinking individualism and collectivism: evaluation of theoretical assumptions and meta-analyses', Psychological Bulletin, Vol. 128, No. 1, p.3.

Pla-Barber, J. and Alegre, J. (2007) 'Analysing the link between export intensity, innovation and firm size in a science-based industry', International Business Review, Vol. 16, No. 3, pp.275-293. 
Prashantham, S. (2006) 'Foreign network relationships and the internationalisation of small knowledge-intensive firms', International Journal of Entrepreneurship Innovation Management, Vol. 6, No. 6, pp.542-553.

Raymond, L. and St. Pierre, J. (2013) 'Strategic capability configurations for the internationalization of SMEs: a study in equifinality', International Small Business Journal, Vol. 31, No. 1, pp.82-102.

Reynolds, P., Bosma, N., Autio, E., Hunt, S., De Bono, N., Servais, I. and Chin, N. (2005) 'Global Entrepreneurship Monitor: data collection design and implementation 1998-2003', Small Business Economics, Vol. 24, No. 3, pp.205-231.

Rodil, Ó., Vence, X. and del Carmen Sánchez, M. (2016) 'The relationship between innovation and export behaviour: the case of Galician firms', Technological Forecasting and Social Change, Vol. 113, pp.248-265.

Ross, L. and Nisbett, R. (1991) The Person and the Situation. Perspectives of Social Psychology, McGraw-Hill, New York.

Schmitt, C., Julien, P-A. and Lachance, R. (2002) 'Pour une lecture des problèmes complexes en PME: approche conceptuelle et expérimentation', Revue Internationale PME Économie et Gestion de la Petite et Moyenne Entreprise, Vol. 15, No. 2, pp.35-62.

Shane, S.A. (1992) 'Why do some societies invent more than others?', Journal of Business Venturing, Vol. 7, No. 1, pp.29-46 [online] https://doi.org/10.1016/0883-9026(92)90033-N.

Sousa, C.M., Martínez-López, F.J. and Coelho, F. (2008) 'The determinants of export performance: a review of the research in the literature between 1998 and 2005', International Journal of Management Reviews, Vol. 10, No. 4, pp.343-374.

St. Pierre, J., Defays, L. and Lacoursière, R. (2015) 'Gestion des risques et exportation des PME québécoises vers les pays asiatiques', Ve Conférence internationale ATLAS-AFMI, Hanoï, 15-16 May.

St. Pierre, J., Julien, P-A. and Morin, M. (2010) 'L'effet de l'âge et de la taille sur la performance financière et économique des PME', Journal of Small Business \& Entrepreneurship, Vol. 23, No. 2, pp.287-306.

St. Pierre, J., Monnoyer, M-C. and Boutary, M. (2006) 'Le rôle des TIC sur le degré d'exportation des PME: une étude exploratoire', 8e Congrès international francophone en entrepreneuriat et $P M E$, CIFEPME, Ch-Fribourg, AIREPME.

St. Pierre, J., Raymond, L., Laurin, F. and Uwizeyemungu, S. (2012) Mondialisation et internationalisation des PME: Le comportement des PME manufacturières québécoises, CIRANO Project Reports.

Sternberg, R. and Wennekers, S. (2005) 'Determinants and effects of new business creation using global entrepreneurship monitor data', Small Business Economics, Vol. 24, No. 3, pp.193-203.

Swierczek, F. and Thanh Ha, T. (2003) 'Motivation, entrepreneurship and the performance of SMEs in Vietnam', Journal of Enterprising Culture, Vol. 11, No. 1, pp.47-68.

Tiessen, J.H. (1997) 'Individualism, collectivism, and entrepreneurship: a framework for international comparative research', Journal of Business Venturing, Vol. 12, No. 5, pp.367-384.

Triandis, H.C. (2001) 'Individualism-collectivism and personality', Journal of Personality, Vol. 69, No. 6, pp.907-924.

Wakelin, K. (1998) 'Innovation and export behaviour at the firm level', Research Policy, Vol. 26, No. 7-8, pp.829-841.

Weerawardena, J., Mort, G.S., Liesch, P.W. and Knight, G. (2007) 'Conceptualizing accelerated internationalization in the born global firm: a dynamic capabilities perspective', Journal of World Business, Vol. 42, No. 3, pp.294-306. 